\title{
Ожидания потребителей о безопасности мяса птицы в связи с заменой кормовых антибиотиков в рационах цыплят-бройлеров
}

Тюрина Д.Г., кандидат экономических наук

Лаптев Г.Ю., доктор биологических наук

Новикова Н.И., кандидат биологических наук

Ильина Л.А., кандидат биологических наук

Йылдырым Е.А., доктор биологических наук

Дубровин А.В.

Филиппова B.A.

Бражник Е.A.

Меликиди В.X.

ООО «БИОТРОФ», Санкт-Петербург

Аннотаиия: Рассматриваются данные об ожиданиях российских потребителей 6 отношении качества и безопасности мяса птицы, полученные с помощью опроса общественного мнения. Проведено сравнение ожиданий потребителей 6 России (2020) и США (2017), быяВившее их неполноту и разрозненность. Однако присутствие 6 мясе антибиотиков больиинством респондентов оценивалось негативно. Поэтому замена 6 рационах бройлеров антибиотических стимуляторов роста на метапробиотик, представляющий собой комбинацию органических кислот и полезных пробиотических микроорганизмоб, будет способствовать больщей рыночной приблекательности полученной таким образом мясной продукции и может стать резербом повышения экономической эффективности птицебодческих предприятий.

Ключебые слова: кормовые антибиотики, бройлеры, опрос общественного мнения, качество мяса, метапробиотик.

Птицеводство как отрасль экономики относится к производству предметов потребления. Однако контакт производителя и потребителя возможен только в вертикально интегрированных холдингах, причем коммуникация производителя и потребителя в этом случае ограничена этикеткой. Как правило, реализация продукции птицеводства потребителю происходит с участием дистрибуторов, которые выступают от имени потребителей, но в своих интересах. Другими словами, бизнес В2C (business-to-consumer) подменяется бизнесом В2B (businessto-business).

Не вызывает сомнения важность качества и безопасности продуктов питания. Однако ис- следования на соответствие качества филе грудки цыплят-бройлеров, проведенные Роскачеством в 2020 г., привели к неоднозначным результатам. Из 15 исследованных образцов различных торговых марок и производителей только 3 (20\%) получили наивысшую оценку. В 9 образцах (60\%) были выявлены побочные продукты хлорирования, в 10 образцах (67\%) были найдены остаточные количества антибиотиков [1].

В этих условиях большое значение принимают опросы общественного мнения. Для изучения мнения потребителей в марте-апреле 2020 г. был проведен опрос потребителей о качестве продукции птицеводства и составе кормов. Опрос проводился в форме анонимного анкетирования среди жителей Санкт-Петербурга. Отдельные вопросы были взяты из исследования потребительских настроений по продукции птицеводства, проведенного в США в 2017 г. в форме опроса покупателей куриного мяса в магазинах [2]. Таким образом, ставшее давно классическим сравнение русских и американцев пополнилось новыми данными. Полученные данные свидетельствуют о том, что настроения покупателей в России частично совпадают с настроениями в США (рис. 1).

При сравнении результатов двух исследований выявляется схожесть потребительских настроений о качестве куриного мяса, несмотря на различия в до- 


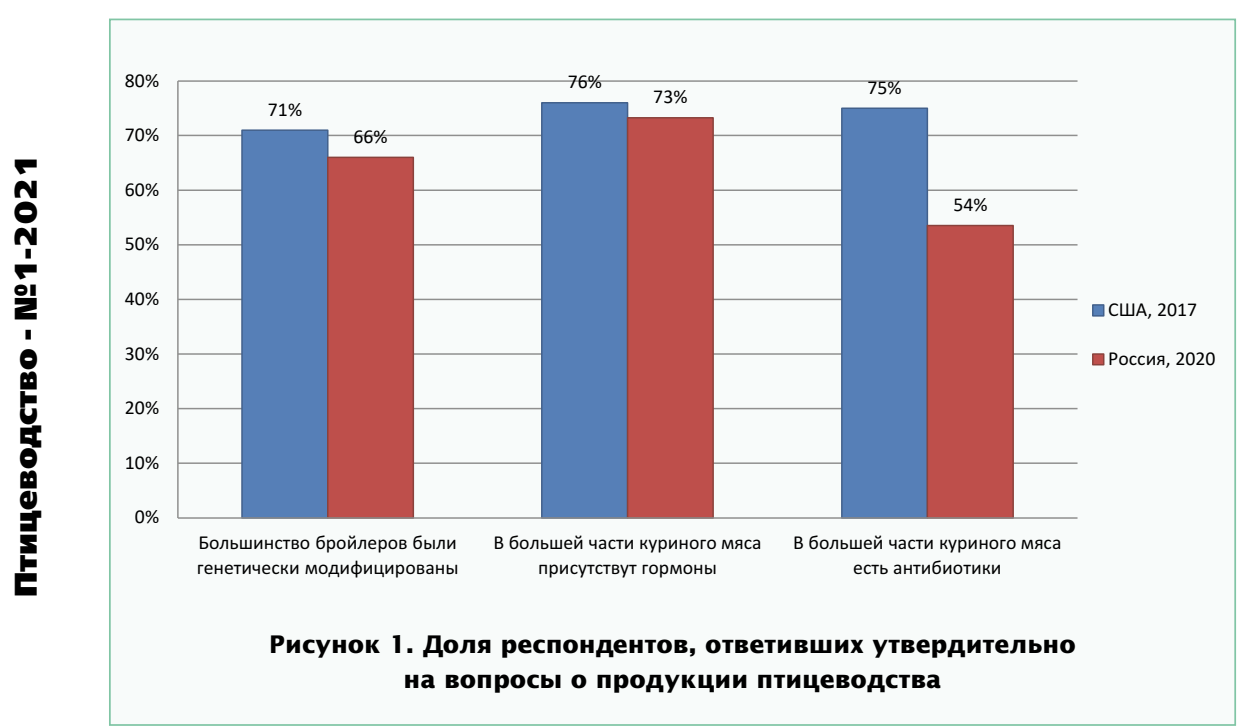

ходах и структуре рационов питания респондентов. 76\% респондентов в США и 73\% респондентов в России уверены, что в большей части куриного мяса присутствуют гормоны. Несколько больше различаются ответы на вопрос о генно-модифицированных бройлерах: 71\% американцев и 66\% россиян верят, что цыплята были генетически модифицированы.

Примечательна разница в ответе на вопрос о присутствии антибиотиков в курином мясе: только 54\% респондентов в России ответили на него утвердительно, в отличие от $75 \%$ респондентов в США. Вероятно, этот факт связан с наличием в магазинах продукции разных технологий выращивания (например, как выращенных без антибиотиков вообще «no antibiotics ever», так и по традиционной интенсивной технологии), соответственным образом маркированной, так что потребитель принимает решение, обладая необходимой информацией.

Продолжение опроса, представленное на рис. 2, позволяет глубже подойти к рассмотрению представлений потребителей о качестве куриного мяса. Вероятно, для потребителя понятия безопасности продуктов питания близки к понятиям о вкусе и полезности, так как 70\% и 67\% ре- спондентов соответственно ответили утвердительно на эти вопросы. Примерно такое же количество потребителей (68\%) готово платить дороже обычного за мясо птицы, при условии, что она выращена без антибиотиков.

Респондентам было предложено охарактеризовать основные компоненты рациона цыплят с точки зрения опасности. Результаты представлены на рис. 3 .

Интересно, что большинство потребителей оценивают только три компонента рационов как безусловно опасные: это антибиотики, кокцидиостатики и бутираты. Относительно последних отметим, что опасность, по всей вероятности, основывается на психоактивном воздействии производных масляной кислоты на человека и использовании их в рекреационных целях.

Вместе с тем, существенная доля опрошенных считает, что сорбенты (29\%), а также кальцийфосфаты (27\%) в составе рациона птицы представляют опасность для человека. Представляется удивительным, что около четверти респондентов видят сорбенты, органические кислоты и источники кальция и фосфора фактором опасности продукции птицеводства.

Тем не менее, в этих цифрах кроются резервы роста рентабельности животноводства. Например, информируя потребителей об отсутствии бутиратов в рационе птицы, производитель сможет привлечь на свою сторону 78\% процентов потребителей. При умелом маркетинговом сопровождении «безбутиратная» курица может быть продана дороже. По результатам опроса можно сделать вывод, что у большинства потребителей есть желание приобретать мясо птицы, свободное от антибиотиков (так как 83\% респондентов считают антибиотики опасными), и они готовы платить премию к цене такой продукции (68\% опрошенных).

Почему же представления потребителей о безопасности так разрозненны? На этот вопрос можно ответить, рассмотрев понятие о рациональности покупателя.

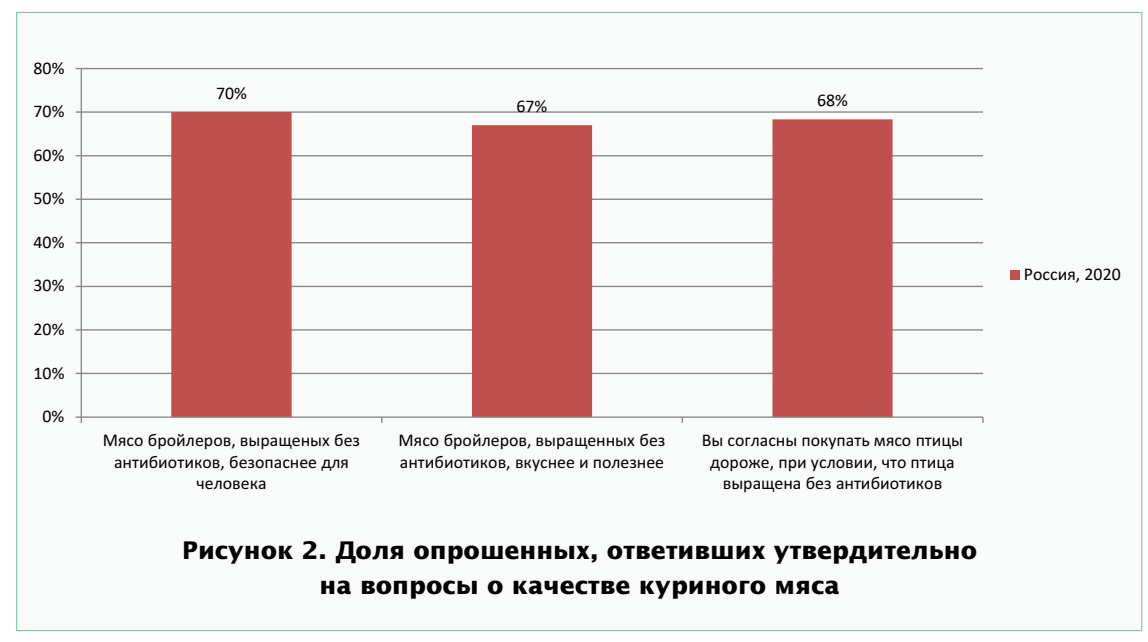




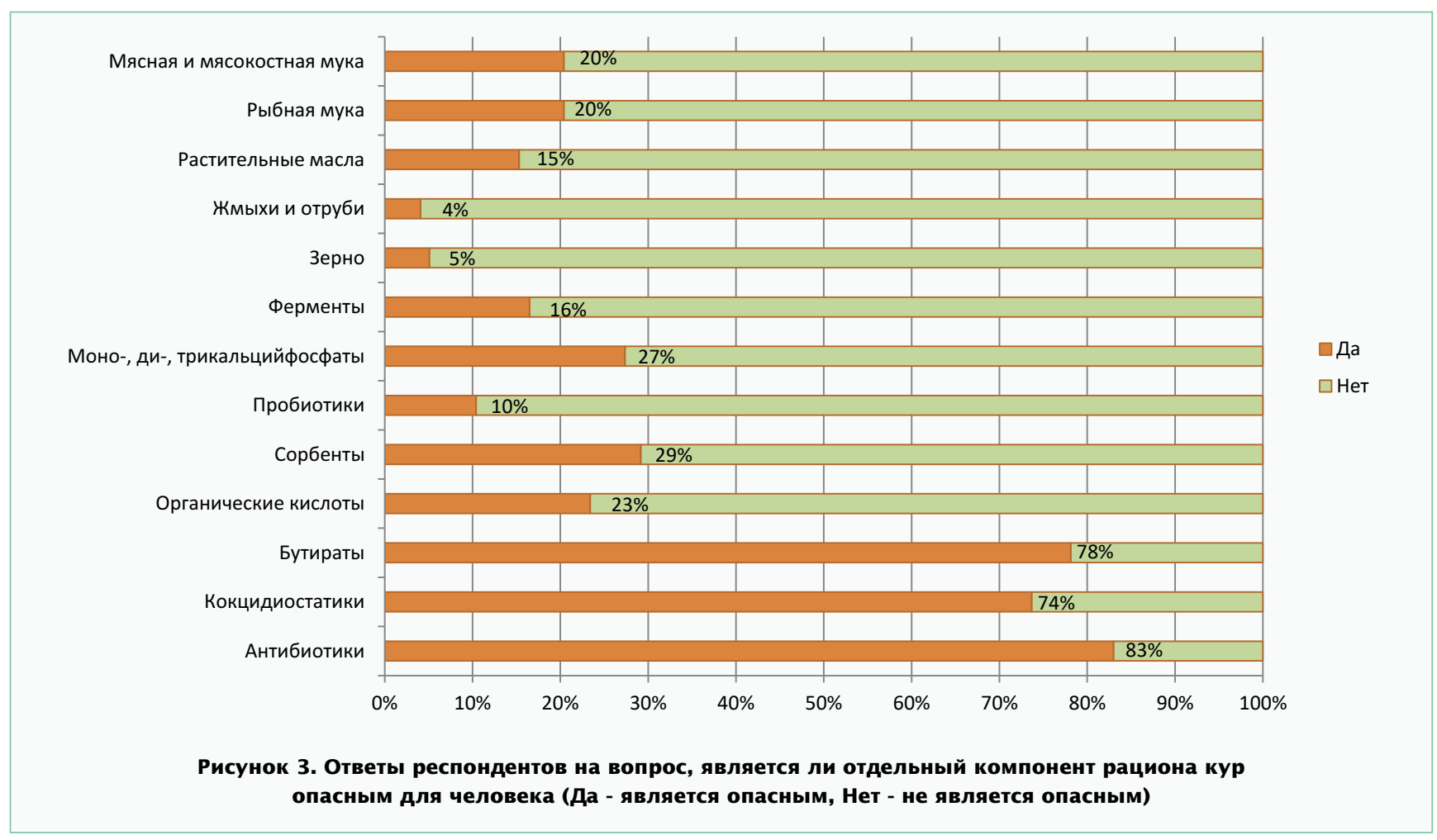

Основным понятием неоклассической микроэкономики является представление о том, что потребитель действует рационально. Однако при более глубоком изучении вопроса о мотивах экономического субъекта становится ясно, что существуют непреодолимые препятствия для рационального поведения, среди которых ограниченность информации и транзакционные издержки. В целом, потребители не всегда поступают рационально и максимизируют собственную полезность.

С современным развитием поведенческой экономики связывают Ричарда Талера (род. 1945), лауреата Нобелевской премии по экономике за 2017 г., в работах которого были раскрыты присущие потребителям когнитивные искажения: ограниченная рациональность, социальные предпочтения и недостаток самоконтроля. Потребители, действуя по своему усмотрению и не всегда рационально, делают свой выбор под влиянием множества факторов, среди которых вкусовые предпо- чтения, личные убеждения, особенности характера, ограничения окружающей среды, религиозные нормы. Потребительский выбор оказывает влияние как на текущее состояние товарных и финансовых рынков, так и на их долгосрочное развитие.

У потребителей сформирован запрос на покупку мяса птицы, выращенной без антибиотиков. Известно, что существует информационный разрыв между технологиями птицеводства и ожиданиями потребителей. Например, в США зафиксировано негативное отношение потребителей к применению антибиотиков и программ освещения [3]. Большинство покупателей не осведомлены о деталях технологических процессов в животноводстве [4]. При этом существует доля потребителей, для которых вопросы кормления и содержания птицы имеют определяющее значение при покупке, в отличие от цены [5]. Результаты проведенного опроса показывают, что настроения потребителей в России частично совпадают с настроениями потребителей в
США. Вероятно, на развитие рынка продукции птицеводства в нашей стране оказывают влияние схожие тенденции.

В последние десятилетия все чаще поднимаются вопросы об опасности распространения антибиотикоустойчивости, хотя развитие резистентности микроорганизмов в ответ на применение антибиотиков описано достаточно давно. Пути распространения резистентности разнообразны и сложны. К ним относятся необоснованное назначение антибиотиков врачами, продажа антимикробных препаратов без рецепта, недостаточный контроль за распространением инфекций в медицинских учреждениях, неудовлетворительные санитарно-гигиенические условия, общее старение населения, увеличение доли иммуннокомпрометированных пациентов, рост глобальной торговли и туризма и др. Особое внимание привлекает животноводство, на долю которого приходится, по разным данным, 50$60 \%$ мирового потребления антибиотиков [6,7]. 
В обществе сформировалось два подхода к ограничению применения антибиотиков: рыночное регулирование и законодательные ограничения. Ряд стран, в том числе Россия, идут по пути запрета отдельных антимикробных препаратов или их групп; так, с 2020 г. в России запрещено применение кормовых антибиотиков.

Эффективность кормовых антибиотиков в течение XX века постепенно снижалась. Выводы об эффективности антибиотиков для ростостимуляции были сделаны, в большинстве своем, на данных, собранных до 1980-х гг. Исследования на цыплятах 1950-1960-х гг. сообщали об увеличении живой массы на 8,5-8,8\% при использовании пенициллина и на 10,212,3\% - тетрациклина [8]. В исследованиях 1968-1980-х гг. медианное увеличение живой массы было определено в 11\% для пенициллина, 8-10\% - для тетрациклина и 4-7\% - для остальных антибиотиков [9]. Тенденция снижения эффективности антибиотиков как стимуляторов роста может быть объяснена рядом причин: как улучшением санитарных условий в птичниках, внедрением селекционных достижений и научно обоснованного кормления, так и распространением резистентных бактерий.

Грэхем с соавт. [10] провели обширное исследование на 7 млн. голов бройлеров в США с целью оценить экономическую эффективность препаратов. Чистый финансовый результат от применения антибиотиков-стимуляторов роста был отрицательным и составил 0,0093 доллара США на каждого цыпленка, так как увеличение массы не окупало стоимость антибиотика в рецепте корма.

Многие исследователи [1 1-14] сходятся в том, что механизм действия кормовых антибиотиков заключается в изменении структур- ного состава микрофллоры желудочно-кишечного тракта. В современных условиях не вызывает сомнения тот факт, что кормовые антибиотики не могут являться единственным средством модулирования микробиома желудочно-кишечного тракта птицы. В качестве замены кормовых антибиотиков предлагается использовать комплексный продукт, представляющий собой композицию органических кислот и солей, а также пробиотических культур. В метапробиотике «Пробиоцид-Ультра» органические кислоты объединены с высушенными в среде культивирования полезными штаммами Bacillus spp.

На крупной бройлерной птицефабрике был проведен производственный эксперимент на двух опытных и двух контрольных корпусах по замене кормового антибиотика нозигептида на метапробиотик «Пробиоцид-Ультра». Основные результаты выращивания бройлеров представлены в табл. 1.

Эти данные подтверждают, что замена кормового антибиотика метапробиотиком «Пробиоцид-Ультра» не приводит к ухудшению зоотехнических показателей. Стоимость комбикорма, израсходованного на получение 1 кг прироста живой массы, увеличивается незначительно - на 1,5\%. При этом наблюдается увеличение среднесуточного прироста живой массы на 2,1\% при той же сохранности поголовья $(97,92 \%$ в среднем в опытных корпусах и 97,83\% в контрольных). Высокий уровень сохранности в контрольных и опытных корпусах может быть объяснен применяемой технологией прореживания стада в возрасте 27-30 дней. Наблюдается повышение конверсии корма в опытных группах в среднем на 1,8\%, однако по сравнению с международным опытом по выведению кормовых антибиотиков из рациона это повышение в 1,3 раза меньше.

Таким образом, полное выведение кормового антибиотика из рецепта рациона не приводит к ухудшению зоотехнических показателей, наоборот, наблюдается небольшое увеличение сохранности и среднесуточного прироста.

Не вызывает сомнения тот факт, что будущее состояние птицеводства определяют потребители. При этом настроения потребителей формируются под влиянием множества движущих сил. Потребители продукции птицеводства не всегда имеют возможность и желание получить достоверную и научно обоснованную информацию о продуктах питания и их производстве. Раскрытие информации для потребителей об отдельных аспектах выращивания птицы может быть драйвером роста прибыли птицеводческих компаний. Полная замена кормового антибиотика на метапробиотик и информирование покупателя об отсутствии кормовых антибиотиков в рационе может быть одним из путей повышения эффрективности птицеводства как коммерческой деятельности.

\section{Литература}

1. Исследование качества фриле грудки цыплят-бройлеров, проведенные Роскачеством. [Электр. ресурс]: https://rskrf. ru/ratings/produkty-pitaniya/myaso-ptitsa-yaytso/kurinaya-grudka-file-2020/; дата обращения 24.12.2020.

2. Karavolias J., Salois M.J., Baker K.T., Watkins K. Raised without antibiotics: impact on animal welfare and implications for food policy // Translat. Anim. Sci. - 2018. - V. 2, No 4. - P. 337-348.

3. Bernard J.C., Pesek Jr. J.D., Pan X. Consumer likelihood to purchase chickens with novel production attributes // J. Agric. Appl. Econ. - 2007. - V. 39, No 3. - P. 581-596.

4. Lusk J.L., Norwood F.B., Pruitt J.R. Consumer demand for a ban on antibio- 


\begin{tabular}{|c|c|c|c|c|c|}
\hline Показатель & $\begin{array}{l}\text { Oпытный } \\
\text { корпус № } 1\end{array}$ & $\begin{array}{c}\text { Опытный } \\
\text { корпус №2 }\end{array}$ & $\begin{array}{l}\text { Контрольный } \\
\text { корпус № } 1\end{array}$ & $\begin{array}{l}\text { Контрольный } \\
\text { корпус №2 }\end{array}$ & $\begin{array}{c}\text { Изменение: } \\
\text { опыт в среднем против } \\
\text { контроля в среднем }\end{array}$ \\
\hline Количество голов на начало опыта & 54556 & 56117 & 56314 & 55351 & -446 \\
\hline $\begin{array}{l}\text { Средняя живая масса при } \\
\text { прореживании, г }\end{array}$ & 1556,37 & 1600,55 & 1574,00 & 1551,93 & $+15,49$ \\
\hline Средняя живая масса при убое, г & 2370,18 & 2400,74 & 2291,19 & 2387,12 & $+46,30$ \\
\hline Сохранность, \% & 97,79 & 98,06 & 98,51 & 97,15 & $+0,09$ \\
\hline Среднесуточный прирост, г & 57,09 & 56,57 & 55,58 & 55,77 & $+1,16$ \\
\hline Конверсия корма, кг/кг & 1,64 & 1,64 & 1,60 & 1,62 & $+0,03$ \\
\hline $\begin{array}{l}\text { Стоимость комбикорма на } 1 \text { кг } \\
\text { прироста, руб. }\end{array}$ & 40,95 & 40,81 & 40,17 & 40,33 & $+0,62$ \\
\hline
\end{tabular}

tic drug use in pork production // Am. J. Agric. Econ. - 2006. - V. 88, No 4. P. 1015-1033.

5. Innes B., Cranfield J. Consumer preference for production-derived quality: Analyzing perceptions of premium chicken production methods // Agribusiness. - 2009. - V. 25, No 3. P. 395-411.

6. Agyare C., Boamah V.E., Zumbi C.N., Osei F.B. Antibiotic use in poultry production and its effects on bacterial resistance. In: Kumar Y., Ed. Antimicrobial Resistance - A Global Threat. IntechOpen, 2019. Chpt. 3.

7. Teuber M. Veterinary use and antibiotic resistance // Curr. Opin. Microbiol. - 2001. - V. 4, No 5. - P. 493-499.

8. Heth D.A., Bird H.R. Growth response of chicks to antibiotics from 19501961 // Poult. Sci. - 1962. - V.41. P. 755-760.
9. Dafwang I.I., Bird H.R., Sunde M.L. Broiler chick growth response to antibiotics, 1981-1982 // Poult. Sci. 1984. - V. 63, No 5. - P. 1027-1032.

10. Graham J.P., Boland J.J., Silbergeld E. Growth promoting antibiotics in food animal production: An economic analysis // Public Health Rep. - 2007. - V. 122 , No 1. - P. 79-87.

11. Джакс Т. Антибиотики в кормлении животных / пер. с англ. А.Б. Линник. - М.: Сельхозгиз, 1959. - С. 14. 12. Егоров Н.С. Основы учения об антибиотиках. - М.: Изд-во МГУ; Наука, 2004. - С. 500.

13. Мюллер 3. Антибиотики в кормлении сельскохозяйственных животных. - М.: Изд. иностр. лит., 1958. C. 20.

14. Coates M. The mode of action of antibiotics // World's Poult. Sci. J. 1953. - V. 9, No 1. - P. 14-16.
Для контакта с авторами:

Тюрина Дарья Георгиевна

E-mail: tiurina@biotrof.ru

Лаптев Георгий Юрьевич

E-mail: laptev@biotrof.ru

Новикова Наталья Ивановна

E-mail: natalia-iv-nov@rambler.ru

Ильина Лариса Александровна

E-mail: ilina@biotrof.ru

Йылдырым Елена Александровна

E-mail: deniz@biotrof.ru

Дубровин Андрей Валерьевич

E-mail: dubrowin.a.v@yandex.ru

Филиппова Валентина

Анатольевна

E-mail: doumova@mail.ru

Бражник Евгений

Александрович

E-mail: bea@biotrof.ru

Меликиди Вероника

Христофоровна

E-mail: veronika@biotrof.ru

\section{Consumers' Expectations Regarding Quality and Safety of Poultry Meat as a Driver for the Substitution of Antibiotic Growth Promoters in Diets for Broilers}

Tiurina D.G., Laptev G.Yu., Novikova N.I., Ilyina L.A., Yyldyrym E.A., Dubrovin A.V., Filippova V.A., Brazhnik E.A., Melikidi V.Kh.

\section{BIOTROF, Ltd. (Saint-Petersburg)}

Summary: Consumers' expectations regarding quality and safety of poultry meat based on the polling survey are observed. We paralleled consumers' expectations in Russia (2020) and USA (2017) and conclude that they are incomplete and isolated. However, the presence of antibiotics is an unambiguously negative factor affecting consumers' attitude. Metaprobiotic based on organic acids and beneficial bacteria may serve as an alternative for the antibiotic growth promoters (ACP) in broiler diets. The substitution of AGP could therefore be a reserve for the higher market attractibility of the meat produced and for the higher profitability of poultry producing enterprises.

Keywords: antibiotic growth promoters, broilers, polling survey, meat quality, metaprobiotic. 